\title{
Karakteristik Bahasa Teks SMS Kolom "Lapor Cik” Harian Rakyat Bengkulu
}

\author{
Syaiful Abid \\ (Corresponding Author) \\ Program Studi Pendidikan Bahasa dan Sastra Indonesia \\ STKIP PGRI Lubuklinggau \\ Email: syaiful2016abid@gmail.com
}

\begin{abstract}
APA Citation: Abid, S. (2021). Karakteristik Bahasa Teks SMS Kolom "Lapor Cik" Harian Rakyat Bengkulu. Silampari Bisa: Jurnal Penelitian Pendidikan Bahasa Indonesia, Daerah, dan Asing, 4(2), 427-442. https://doi.org/10.31540/silamparibisa.v4i2.1493
\end{abstract}

\begin{abstract}
Abstrak
Tujuan penelitian ini adalah untuk mendeskripsikan pemahaman yang tepat, mendalam, dan rinci tentang, 1) penggunaan bahasa dalam teks SMS kolom "Lapor Cik" Harian Rakyat Bengkulu, ditinjau dari sudut pandang formalitas, penggunaan bahasa gaul (slang), penyingkatan kata, (2) gaya bahasa yang digunakan dalam teks SMS kolom "Lapor Cik" Harian Rakyat Bengkulu. Jenis penelitian ini adalah penelitian deskriptif. Alat analisis yang digunakan adalah kualitatif yakni dengan menginterprestasi makna yang terkandung dalam teks SMS. Hasil penelitian menunjukkan bahwa: 1) penggunaan bahasa SMS "lapor cik" terdapat beberapa penggunaan bahasa, yaitu bahasa formal dengan persentase $0,03 \%$, penggunaan bahasa asing yang disertakan bahasa Indonesia, atau sering disebut dengan language mixing (campur bahasa) dengan persentase $0,02 \%$, penggunaan bahasa gaul (slang) dengan persentase $0,14 \%$, dan penyingkatan kata dengan persentase $0,34 \%$, artinya dari keseluruhan penggunaan bahasa SMS "Lapor Cik" didominasi oleh penyingkatan kata. Kemudian, 2) penyingkatan bahasa SMS "Lapor Cik" menggunakan kliping sebagai salah satu bagian dari proses pembentukan kata baru, sedangkan dalam konteks SMS Lapor Cik, kliping digunakan tidak untuk membentuk kata-kata baru, tetapi untuk menghemat karakter dan tentu saja pulsa, dan (3) pada style (gaya) yang dapat dijumpai dalam SMS "Lapor Cik" Harian Rakyat Bengkulu yakni: (a) majas pertentangan, (b) gaya bahasa perbandingan, (c) dan gaya bahasa bertautan.
\end{abstract}

Kata kunci: karakteristik bahasa, teks SMS, kolom, surat kabar 


\title{
Language Characteristics of SMS Text "Lapor Cik" Harian Rakyat Bengkulu
}

\begin{abstract}
The purpose of this study was to describe a precise, in-depth, and detailed understanding of, 1) the use of language in the SMS text of the "Lapor Cik" column of the Harian Rakyat Bengkulu, in terms of formality, the use of slang (slang), word abbreviations, (2) the style of language used in the SMS text of the "Lapor Cik" column of the Harian Rakyat Bengkulu. This type of research is descriptive research. The analytical tool used is qualitative, namely by interpreting the meaning contained in the SMS text. The results showed that: 1) the use of the SMS language "Lapor Cik" there are several language uses, namely formal language with a percentage of $0.03 \%$, the use of a foreign language that includes Indonesian, or often referred to as language mixing with a percentage of $0.02 \%$, the use of slang with a percentage of $0.14 \%$, and abbreviation of words with a percentage of $0.34 \%$, meaning that from the overall use of the SMS language "Lapor Cik" is dominated by abbreviations. Then, 2) shortening the language of the SMS "Lapor Cik" using clipping as a part of the process of forming new words, while in the context of SMS Lapor Cik, clipping is used not to form new words, but to save characters and of course credit, and (3) on the styles that can be found in the "Lapor Cik" SMS of the Harian Rakyat Bengkulu, namely: (a) oppositional figure of speech, (b) comparative language style, (c) and linked language style.
\end{abstract}

Keywords: language characteristics, SMS text, column, newspaper

\section{A. Pendahuluan}

Perkembangan teknologi komunikasi telah membawa dampak yang sangat luas dalam kehidupan manusia. Kehadiran alat komunikasi seperti telepon seluler (ponsel) misalnya, dengan segala kelebihannya telah membuat banyak perubahan dalam berbagai aspek kehidupan masyarakat (Syamsi, 2015). Dengan adanya ponsel, komunikasi antar individu pada aspek-aspek kehidupan tersebut telah menjadi semakin praktis, murah, mudah, serta tidak mengenal batas waktu dan tempat (Susanti, 2013). Cukup dengan menekan perintah call untuk menghubungi seseorang yang namanya terekam di phonebook kita atau cukup dengan mengetik pesan singkat atau SMS (Short Message Services).

Teks SMS sekarang dapat ditemukan di beberapa media cetak diantaranya adalah kolom "Lapor Cik" Harian Rakyat Bengkulu. Kolom ini merupakan kolom khusus yang memuat pesan berupa SMS dari semua kalangan masyarakat baik sebagai pengaduan, peringatan maupun tujuan lainnya yang ingin disampaikan kepada orang atau pihak lain. Teks SMS pada kolom "Lapor Cik" Harian Rakyat Bengkulu merupakan kolom yang akurat dalam melihat bentuk teks SMS, sebab di sana terdapat SMS yang benar-benar berupa singkatan buatan penulis dan terdapat pula SMS yang ditulis dengan kata dan kalimat sebenarnya.

Teks SMS merupakan wujud baru wacana tulisan yang dihipotesiskan mempunyai karakteristik tersendiri. Hal ini menjadikan SMS salah satu wujud teks yang belum mendapat perhatian dari pemerhati bahasa Samijayani dkk. (2015). Penelitian yang menjadi acuan dalam penelitian ini diantaranya penelitian Samijayani dkk. (2015) tentang perancangan sistem penulisan teks pada running text menggunakan bahasa SMS. Selain itu, penelitian Ariyanti \& Fentaria (2017) yang mengangkat judul "Penggunaan Konjungsi dalam Wacana Kriminal Kolom

Silampari Bisa: Jurnal Penelitian Pendidikan Bahasa Indonesia, Daerah, dan Asing Vol. 4, No. 2, 2021 
Borgol di Surat Kabar Rakyat Bengkulu Edisi November - Desember 2016". Hasil penelitian ini menunjukkan bahwa penggunaan konjungsi dalam surat kabar Rakyat Bengkulu belum adanya keefektifan dan variatif. Hal ini, disebabkan oleh kurangnya pengetahuan penulis berita ataupun tim editor dalam memahami tentang beberapa jenis dan keberfungsian dari konjungsi.

Berdasarkan uraian di atas fenomena teks SMS perlu mendapat perhatian dan dijadikan objek kajian, melalui kajian ini diharapkan dapat terungkap tentang karakteristik bahasa tulis SMS pada kolom "Lapor Cik" Harian Rakyat Bengkulu sebagai penyampai makna kepada penerima pesan.

\section{B. Metode Penelitian}

Metode yang digunakan dalam penelitian ini adalah metode deskriptif. Penelitian ini berusaha mendeskripsikan fenomena kebahasaan pada teks SMS kolom "Lapor Cik" Harian Rakyat Bengkulu. Pendeskripsian ini mencakup usaha merekonstruksi dan menemukan karakteristik dan makna teks SMS kolom "Lapor Cik" Harian Rakyat Bengkulu yang menjadi data penelitian.

Data penelitian ini diambil dari surat kabar Harian Rakyat Bengkulu edisi Agustus 2011. Instrumen dalam penelitian ini adalah daftar cek, maksudnya yakni daftar teks SMS yang telah ada di kolom "Lapor Cik" Harian Rakyat Bengkulu langsung menjadi alat penelitian dalam menemukan, menyaring, menafsirkan, dan mengkaji data yang akan dibahas.

Teknik pengumpulan data dalam penelitian ini menggunakan teknik dokumentasi, yakni data diambil langsung dari dokumen tertulis SMS pada kolom "Lapor Cik" Harian Rakyat Bengkulu edisi Agustus 2011. Adapun model analisa ini menggunakan persentase dan komponen interaktif yang terdiri dari: reduksi data, salinan data, dan penarikan kesimpulan (Moleong, 2013).

\section{Hasil Penelitian dan Pembahasan}

\section{Hasil Penelitian}

a. Deskripsi Seputar SMS Lapor Cik

SMS "Lapor Cik" merupakan salah satu halaman yang terdapat dalam surat kabar Harian Rakyat Bengkulu (RB) yang terbit setiap hari. Kolom SMS "Lapor Cik" senantiasa terletak pada halaman 19 di paling atas. SMS "Lapor Cik" ini berwujud sebuah SMS yang menggambarkan peristiwa atau kejadian-kejadian aneh, lucu, konyol, dan tak biasa. Kejadian-kejadian aneh itu dikreasikan dengan berbagai cara, yang dikemas dalam bentuk SMS (Short Message Service). Bentuk fisiknya berupa rentetan kalimat dan dijalin menjadi pesan yang singkat. Karena SMS "Lapor Cik" yang ditampilkan berisi kritikan, himbauan, dan saran-saran kepada pemerintah Bengkulu khususnya.

Penulis SMS "Lapor Cik" ini adalah pembaca Harian Rakyat Bengkulu yang merupakan masyarakat Bengkulu dan sekitarnya. Hal ini terlihat dari para pengirim SMS "Lapor Cik" ini yang sebagian besar berasal dari kota dan daerah. Dalam perkembangannya, para pembaca SMS "Lapor Cik" ini semakin luas seiring dengan meningkatnya oplah Harian Rakyat Bengkulu. Selanjutnya, cerita (yang berasal dari pembaca) ini diolah oleh redaktur Harian Rakyat Bengkulu dengan mengganti nama-nama pelaku dengan nomer handpone pengirim.

Dalam kaitannya dengan teori kebahasaan, pencipta SMS "Lapor Cik" ini ternyata secara tidak sadar telah memperhitungkan berbagai aspek komponen 
tutur di dalam mengkreasikan karyanya. Komponen-komponen setting, participant (s), act of sequence, key, norm of interaction, instrument, dari SMS "Lapor Cik" ini agaknya telah pula diperhitungkan, sehingga SMS "Lapor Cik" ini memiliki sifat-sifat tertentu. Kekhasan yang terdapat di dalamnya yaitu bahasanya mudah dipahami, bersifat semi formal, istilah-istilah yang sering dijumpai, mengandung alih kode, serta berisi permainan bahasa, yang keseluruhannya merupakan upaya untuk menyampaikan pendapat, kritikan, serta menghibur para pembaca Harian Rakyat Bengkulu. Permainan bahasa yang berupa plesetan dan berbagai bentuk makna kata juga merupakan ciri yang sangat penting di dalam SMS "Lapor Cik".

\section{b. Persentase Penggunaan Bahasa SMS Lapor Cik}

Berdasarkan hasil penelitian yang dilakukan terhadap penggunaan SMS "Lapor CIK", maka dapat diketahui tingkat persentase penggunaan SMS "Lapor CIK" berdasarkan kelas penggunaan dan gaya bahasa SMS "Lapor CIK". Secara keseluruhan dapat dikelompokkan menjadi dua kelompok yakni persentase penggunaan SMS "Lapor CIK" dan gaya bahasa yang ditemui pada SMS "Lapor CIK" itu sendiri, adapun persentase penggunaan SMS "Lapor CIK" tersebut sebagai berikut.

Tabel 1. Persentase Penggunaan Bahasa SMS Lapor Cik

\begin{tabular}{clc}
\hline No. & \multicolumn{1}{c}{ Jenis } & Persentase (\%) \\
\hline 1. & Penggunaan bahasa formal & $0,03 \%$ \\
\hline 2. & $\begin{array}{l}\text { Penggunaan bahasa asing yang disertakan bahasa } \\
\text { Indonesia (language mixing) }\end{array}$ & $0,02 \%$ \\
\hline 3. & Bahasa slang & $0,14 \%$ \\
\hline 4. & Penyingkatan kata & $0,34 \%$ \\
\hline
\end{tabular}

Berdasarkan tabel 1 dapat kita ketahui bahwa tingkat persentase tertinggi dalam penggunaan SMS "Lapor Cik" terdapat pada penyingkatan kata dengan persentase $0,34 \%$. Jumlah persentase tersebut memberikan penjelasan bahwa secara keseluruhan bahasa yang digunakan dengan penyingkatan kata. Hal tersebut digunakan untuk mempermudah dan pengurangan biaya pengiriman SMS. Pada penggunaan bahasa formal pada SMS "Lapor Cik" 0,03\%, hal tersebut menunjukkan bahwa secara keseluruhan penggunaan bahasa formal yang terdapat pada SMS "Lapor Cik" tidak sepenuhnya digunakan. Untuk penggunaan bahasa asing yang disertakan bahasa Indonesia (language mixing) dengan persentase $0,02 \%$. Hal tersebut menunjukkan bahwa penggunaan bahasa asing (language mixing) dalam SMS "Lapor Cik" jarang digunakan. Pada penggunaan bahasa slang dengan persentase $0,14 \%$ tingkat jumlah persentase tersebut menunjukkan bahwa sedikitnya bahasa gaul (slang) yang digunakan pada SMS "Lapor Cik". Dari keseluruhan persentase yang ada diketahui bahwa persentase tertinggi terdapat pada penyingkatan kata, artinya dalam penyampaian SMS "Lapor Cik" didominasi menggunakan penyingkatan kata.

Tabel 2. Gaya Bahasa SMS Lapor Cik

\begin{tabular}{clc}
\hline No. & \multicolumn{1}{c}{ Jenis } & Persentase (\%) \\
\hline 1. & Gaya bahasa berdasarkan pilihan kata & $0,04 \%$ \\
\hline 2. & Gaya bahasa berdasarkan struktur kalimat & $0,04 \%$ \\
\hline 3. & Gaya bahasa perbandingan & $0,05 \%$ \\
\hline 4. & Gaya bahasa pertentangan & $0,05 \%$ \\
\hline 5. & Gaya bahasa pertautan & $0,04 \%$ \\
\hline
\end{tabular}

Silampari Bisa: Jurnal Penelitian Pendidikan Bahasa Indonesia, Daerah, dan Asing Vol. 4, No. 2, 2021 
Dari tabel 2 di atas gaya bahasa berdasarkan pilihan kata 0,04\%, gaya bahasa berdasarkan struktur kalimat $0,04 \%$, gaya bahasa perbandingan $0,05 \%$, gaya bahasa pertentangan $0,05 \%$, dan gaya bahasa pertautan $0,04 \%$. Dari penggunaan gaya bahasa SMS "Lapor Cik" persentase tertinggi terdapat pada gaya bahasa pertautan, artinya dalam penyampaian SMS "Lapor Cik" didominasi oleh gaya bahasa pertautan.

\section{Pembahasan}

a. Penggunaan Bahasa Formal

Penggunaan bahasa yang baik dan benar adalah salah satu syarat yang sebaiknya dipenuhi dalam menuliskan SMS walaupun memang SMS memiliki keunikan yaitu bahasa yang singkat sesuai dengan konteks penuturnya (Sriningsih, 2017; Sirulhaq \& Chaer, 2019; Amelia, 2015; Morelent, 2013). Pemenuhan syarat tersebut diperlukan agar kita mempunyai aturan tentang bahasa yang digunakan. Untuk lebih mengetahui penggunaan bahasa tersebut dapat dilihat pada SMS D1 di bawah ini.

\section{BAGAIMANA HUKUMNYA 6285758120717 \\ PAK USTAD. Bagaimana hukumnya: Ibadah haji, sholat, puasa, zakat, infak, sadakoh, makan, pakaian, tempat tinggal, kendaraan, kebun, deposito, dll. Semuanya dan HARTA HARAM basil: korupsi, suap, memeras, menipu, mencuri, riba, judi, zina, miras, maksiat. (D1)}

Dari SMS Lapor Cik di atas dapat kita ketahui bahwa penggunaan kata tersebut dapat dilihat berdasarkan susunan kata yang bersifat formal dan dapat dipahami oleh penerima SMS. Pada data (D1) di atas terlihat "PAK USTAD. Bagaimana hukumnya: Ibadah haji, sholat, puasa, zakat, infak, sodakoh, makan, pakaian, tempat tinggal, kendaraan, kebun, deposit,"

\footnotetext{
"Jangan hanya puasa menahan nafsu lapar \& haus saja. Tetapi jg puasa menahan nafsu korupsi, soap, mencuri, menipu, memeras, zina, judi, maksiat, termasuk setelah selesai dibulan ramadhon nanti.!! Jaga Kesucian Bulan Ramadhan” (D2)
}

Pada data D2 di atas dapat lihat pada kalimat "Jangan hanya puasa menahan nafsu lapar \& haus saja. Tetapi jg puasa menahan nafsu korupsi, soap, mencuri, menipu, memeras, zina, judi, maksiat, termasuk setelah selesai dibulan ramadhon nanti.!! Jaga Kesucian Bulan Ramadhan”. Kedudukan klausa di dalam kalimat tersebut adalah setara dan sama derajatnya, yang satu tidak lebih tinggi atau lebih rendah dari yang lain; atau yang satu mengikat atau terikat pada yang lain. Kalimat tersebut mempunyai kedudukan yang bebas, sehingga kalau yang satu ditinggalkan, maka yang lain masih tetap berdiri sebagai sebuah klausa. Dalam bahasa formal tersebut digunakan sangat singkat dan jelas mungkin agar tidak membuat jumlah halaman SMS menjadi dua yang berarti membayar dua harga SMS

\section{b. Penggunaan Bahasa Asing yang Disertakan Bahasa Indonesia (Language Mixing)}

Penggunaan bahasa asing yang disertakan bahasa Indonesia atau sering disebut dengan language mixing atau yang sering disebut campur bahasa atau campur kode adalah proses penggunaan dua bahasa yang berbeda atau lebih 


\section{Syaiful Abid}

Karakteristik Bahasa Teks SMS Kolom "Lapor Cik" Harian Rakyat Bengkulu

dalam sebuah SMS. Language mixing dalam SMS dapat terjadi karena beberapa alasan. Alasan yang paling umum digunakan adalah karena faktor trend (Farouq, 2019). Fenomena ini dapat dijumpai pada SMS Lapor Cik di bawah ini.

Buat aparat penegak hukum di SPBU pondok kelapa banyak tengki motor modif buat menimbun BBM tolong tertib kan, please!! (D3)

Pada data di atas, kita dapat melihat munculnya beberapa kosakata atau kalimat asing seperti "please". Penggunaan kosakata atau kalimat asing menjadi sebuah gaya tersendiri dan banyak ditemukan dalam penulisan SMS Lapor Cik. Dalam fenomena ini dijumpai style language mixing seperti yang terdapat pada kalimat (D3) pada kata please kata tersebut terdapat mata akhiran kalimat yang menggunakan bentuk tersendiri yang bertujuan untuk meminta.

\footnotetext{
Berdoa Ketika Berbuka Puasa Merupakan Salah 1 Waktu Doa Yang Mustajab Rasulullah Bersabda : Tiga Orang Yang. Tdak Akan Di Tolak Doanya1 Dna Orang Yang Berpuasa .. 2Doa Imam/ Pemimpin Yang Adil 3 Doa Drang Yang Di Zalimi HR,TIRMIDZI IBNU MAJAH \& IBNU HIBBAN ... Apalagi Detik2 Menjelang Berbuka, Insya Allah Do'anya Mustajab ... ... Adapun Doa Yang Di Ajarkan Nabi : Dzahabadh Zhoma U Wabtallatil Uruqu Wa Tsabatal Ajru Insya Allah. Artinya Telah Hilang Dahaga Dan Telah Basah Urat2 Dan Telah Di Tetapkan Pahala Insya Allah HR.ABU DAWUD BAIHAQI HAKIM IBNU SUNNI (D4)
}

Pada kalimat (D4) akhiran mustajab menunjukkan arti tujuan maksud tertentu. Bahasa SMS ini biasa digunakan para orang untuk pesan yang bersifat lawakan, pesan romantis untuk kekasih dan orang yang disayang, dan secara umum biasa digunakan oleh orang yang biasa menggunakan bahasa asing dalam berkegiatan.

\section{c. Bahasa Slang}

Adapun SMS yang terdapat pada Lapor Cik di Harian Rakyat Bengkulu penggunaannya seperti terlihat di bawah ini.

Diskotik dan cape tetap diawasi, buka jam 21.00. Sp 00.00, potong leher aku kalau dipatuhi kpn kau cek, pengunjtng dan karyawan hrs pakaian yg sopan, emangnye mau keondangan dak lakulah kafe, menghindari minurnan keras jadi minum apo coy? Kopi ha ha ha ha ha ha dasar kuper (D5)

Pada SMS Lapor Cik yang terdapat pada (D5) seperti pronomina "Coy" yang berarti "teman panggilan kepada sebaya". Pada kata kedua "kuper" yang diambil dari kata "kurang pergaulan" dan sering disingkat dengan "kuper". Bahasa slang umumnya diucapkan sama seperti bahasa Indonesia dan terkadang diadaptasi dari bahasa asing.

"Gw yakin itu foto asli....yang sdh kakek2 aja cabuli " (D6)

Pada "GW" memberikan arti istilah "gue" atau " saya" kata tersebut digunakan kalangan remaja masa kini, kata tersebut digunakan dalam kehidupan sehari-hari

"Apola kerjo guru yang satu tuh..SH makan gaji buto, uda HONORER,,LEBAY SOK PINTARHIDUP PULO” (D7) 


\title{
Syaiful Abid
}

Karakteristik Bahasa Teks SMS Kolom "Lapor Cik" Harian Rakyat Bengkulu

Pada kata "Lebay" yang berarti " lembut", kata tersebut digunakan untuk memberikan penjelasan terhadap orang yang terlalu lembut dalam penampilan atau perfoman, ini banyak digunakan oleh kalangan selebritis dan anak muda.

\section{d. Penyingkatan Kata}

Penyingkatan kata sering juga kita sebut dengan Clipping yang berarti fenomena sebuah kata yang terdiri dari dua suku kata atau lebih yang dipotong menjadi lebih pendek (Yule, 1996). Dalam linguistik, cliping adalah salah satu bagian dari proses pembentukan kata baru, sedangkan dalam konteks SMS Lapor Cik, clipping digunakan tidak untuk membentuk kata-kata baru, tetapi untuk menghemat karakter dan tentu saja pulsa.

Qt hidp tigi dl $\underline{\mathbf{t}} \mathbf{4}$ yaitu bumi $\underline{\mathbf{Q t}}$ mMiki 1 tjuan yaltU AKHIrt Tpi qt brbda cra u/ brthn hdp. Jd pRnahkn kLian mrASAkn tnpa mNrima gJl dim 1 bln (D8).

Pada data (D6), terdapat kalimat gaul "t4" yaitu bumi "qt". Kalimat ini adalah kalimat dari seorang karyawan yang mengeluhkan akan telatnya penerimaan gaji dalam bulan tertentu. Dalam kalimat tersebut " 4 " menunjukkan sebuah kata "tempat" penggabungan ponem tersebut digunakan untuk menghemat karakter sms yang akan dikirimkan.

Lapor cikdirut PDAM MANNA yg (yang) masuk 3 besar tu tiong pak BUPATI can lah yg tepat dan tau tentang PDAM. Jangan sampai tidak ngerti tentang PDAM.tks. (D9)

Dari data di atas kita dapat melihat beberapa kata mengalami proses clipping seperti, "yg" (yang) penyingkatan kata tersebut digunakan untuk mempersingkat kata dalam pengiriman sms, dan jika dilihat dari clipping di dalam SMS tersebut membentuk suatu pola kata baru yang mempunyai arti.

Sy (saya) cuma mau bilang apa lalau mau pintar hams bnykuang skrng anak sy berumur 8 thn tp susah sx untuk sekolah 'gara2 peraturan yg di buat bpk wa (D10)

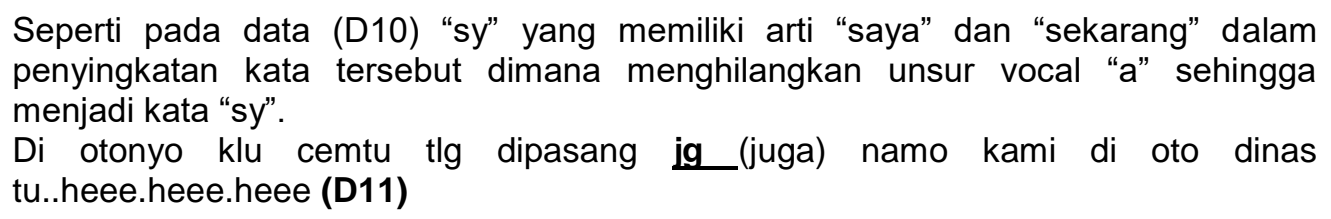
penyingkatan kata tersebut dimana menghilangkan unsur vocal "a" sehingga menjadi kata "sy".

Di otonyo klu cemtu tlg dipasang ig (juga) namo kami di oto dinas tu..heee.heee.heee (D11)

\begin{abstract}
Menyegerakan berbuka puasa merupakan hal yang sangat di anjurkan oleh rasullullah.....karena didalamnya ada banyak sekali kebaikan....bahkan selain kebiasaan para nabi, juga merupakaan pembeda puasa kita dg (dengan) puasanya umat lain, rasullullah bersabda: agama ini akan senantiasa menang selama manusia kaum muslimin mempercepat buka puasanya (D12)
\end{abstract}

Pada penyingkatan kalimat di atas "jg" yang berarti "juga" dan "dg" (dengan) penyingkatan kata tersebut dengan menghilangkan huruf vocal "u" dan vokal "a" sehingga menjadi "jg" yang berarti juga dan "dg" yang berarti " dengan".

\section{e. Gaya Bahasa SMS Lapor Cik}

Banyak sekali aspek-aspek stilistika ditemukan dalam bahasa SMS, baik itu dalam bentuk tampilan pesan, pemilihan kata, grammatikal, isi dari teks SMS, maupun cara penyampaian pesan yang ada di dalam SMS tersebut. Keluasan 


\section{Syaiful Abid}

Karakteristik Bahasa Teks SMS Kolom "Lapor Cik" Harian Rakyat Bengkulu

aspek-aspek SMS inilah yang menyebabkan pada artikel ini, aspek-aspek yang dijumpai pada SMS "Lapor Cik" antara lain:

1) Gaya Bahasa Berdasarkan Pilihan Kata

Pada SMS "Lapor Cik" hanya ditemukan gaya bahasa berdasarkan pilihan kata. Dalam gaya bahasa ini, pilihan kata-katanya adalah kata-kata populer dan kata-kata percakapan lebih longgar dibandingkan dengan gaya bahasa resmi dan gaya bahasa tak resmi karena tidak diperhatikan morfologisnya, adapun gaya bahasa tersebut sebagai berikut.

YTH RB TV, tobong diekspose diINVESTIGASI RB TV ulah petugas SPBU sukarja yg melakukan pengecoran ke JERIGEN untk para SPIKULAN dan pengecer. dan jam 130 S/D jam 5 subuh Terjdi hampin tiap malam. (D13)

Pada sms tersebut diatas dijumpai pilihan kata resmi seperti pada kata "yth" kata tersebut merupakan kata gaya bahasa resmi atau bahasa yang digunakan lebih santun oleh penerima sms dan yang sering digunakan pada masyarakat umum.

"UCAPAN TERIMAH KAS)H YG SEBESAR2 NYA TUK BANGKEN ,KARENA MEMBUAT KAMI DI PASAR PANORAMA NI IDAK BISA MAKAN DNG LAVAK IAGI DAN MEMBUAT MACET KENDARAAN. BRAVO BANG KENHI)" (D14)

Pada sms tersebut diatas "UCAPAN TERIMAH KAS)H YG SEBESAR2 NYA" adalah pilihan kata yang bersifat formal karena kata tersebut digunakan dengan kesan formal dan santun.

"Ass..selamat pagi dan MERDEKA, knapa management RBTV tdk menayangkan acra pengibaran bendera, sngt disayangkan Wassalam. " (D15)

Pada kata "Ass..selamat pagi dan MERDEKA" adalah suatu ucapan pilihan kata yang ditujukan kepada seseorang ataupun umum dengan maksud dan tujuan.

\section{2) Gaya Bahasa Berdasarkan Struktur Kalimat}

Struktur sebuah kalimat dapat dapat dijadikan untuk menciptakan gaya bahasa yang bersifat periodik dalam kalimat (Keraf, 2004:112). Adapun gaya bahasa berdasarkan Struktur Kalimat pada SMS Lapor Cik sebagai berikut.

Selamat atas dilantik menjadi ass semoga tepikir ndak mbayar jln puyang Ratu yg aku kerjauka th 2005 atas permintaan agusrin melalui.... Allahuakbar pilkada (D16)

Pada data (D16) diatas menunjukkan bahwa kalimat tersebut bersifat periodik, bila yang mendapat penekanan ditempatkan pada akhir kalimat.

Kepada yang terhormat pit gup dan wail kota apa memeng pns lulusan sma bisa jadi kasubak tu seperti ibu hindun bendahara di diknas pnopinsi dulu saya pernah tanya kebagian ke pegawayan kata riya tidak cukup pangkat harus 3 e sedang kan ibu hindun $3 \mathrm{~b}$ apa ibu banyak uang nya ya dengan 25 sampai 40 juta. (D17)

Pada kalimat di atas merupakan kalimat yang mendapat penekanan pada awal kalimat. Kemudian kalimat tersebut berimbang yang mengandung dua bagian kalimat atau lebih yang kedudukannya sama tinggi atau sederajat.

\section{3) Gaya Bahasa Perbandingan}

Pada SMS Lapor Cik terdapat beberapa gaya bahasa perbandingan yang ditemukan gaya bahasa perumpamaan. Perumpamaan adalah gaya bahasa 
perbandingan dua hal yang pada hakekatnya berlainan dan yang sengaja kita anggap sama, pada SMS Lapor Cik sebagai berikut.

Dia yang seenaknya orang lain yang disergahnya, tak peduli sebaya bapaknya, sebaya datuknya. Pak kapolda/kalau brpakaian nondinas pun bisa dihardiknya. ( D18)

SMS di atas menunjukkan bahwa gaya bahasa perumpamaan, pada SMS "Dia yang seenaknya orang lain yang disergahnya, tak peduli sebaya bapaknya, sebaya datuknya". Hal tersebut menggambarkan tingkat kekuasaan seorang pemerintah atau pejabat hanyalah mementingkan diri sendiri.

Cape dan diskotik ngak ada hubungannya dengan bulan ramadhan karena sekarang ni zaman edan. Allah sudah menetapkan dua pilihan (surga atau neraka) silahkan aja masyarakat pilih sendiri jangankan perintah pemda perintah Allah saja banyak yang engkar. (D19)

Data (D16) kata kata "Cape dan diskotik ngak ada hubungannya dengan bulan ramadhan karena sekarang ni zaman edan". Hal tersebut memberikan informasi perbandingan perumpamaan umat manusia yang berhubungan dengan Tuhan Semesta Alam.

\section{Lapor Cik. Akan kalian habiskan Kekayaan Bengkulu han ni...? silahkan.. . Karena lebih pantas Perut kalian BUNCIT dan pada Nasib Anak2 dn Cucu2 Kalian di masa DEPAN Marhaban ya Ramadhan 1432 H (D20)}

Kata perumpamaan di atas memberikan makna bahwa dalam perbandingan tersebut bahwa tingkat perbandingan yang digunakan bersifat eksplisit.

\section{4) Gaya Bahasa Pertentangan}

Pada gaya bahasa pertentangan ditemukan beberapa gaya bahasa yang dipakai pada SMS Lapor Cik, adapun gaya bahasa tersebut sebagai berikut. a. Litotes

Keraf (2004:132) menyatakan bahwa litotes adalah semacam gaya bahasa yang dipakai untuk menyatakan sesuatu dengan tujuan untuk merendahkan diri. Suatu hal yang dinyatakan kurang dari keadaan sebenarnya, atau suatu pikiran dinyatakan dengan menyangkal lawan katanya, pada SMS Lapor Cik sebagai berikut.

\section{Selamat atas dilantik menjadi ass semoga tepikir ndak mbayar jalan Puyang Ratu} yang aku kerja th 2005 atas permintaan A.. melalul.... Ailahuakbar (D21)

Dari SMS di atas dapat dilihat bahwa pada SMS tersebut menyatakan sesuatu dengan dengan sindiran, pada gaya bahasa yang digunakan tersebut pengirim SMS menyampaikan aspirasi yang dimiliki.

\footnotetext{
Uang $50 \mathrm{rb} / \mathrm{i} 00 \mathrm{rb}$, tinggalkan iah pola2 pemikiran ada uang dipiiih tak ada uang tdk dipiiih, karena pemikiran seperti itu keliru besar, calon yang menghambur2kan duit sudah pasti calon yang gila dengan kekuasaan dan kekayaan serta calon yg teiah menghabiskan dana yang banyak, sudah pasti akan mengembalikan modainya, jd iah pemiiih yang cerdas dan piiihiah calon yg memiliki motivasi untuk membangun. Putra Daerah atau bukan tdk jd masalah (D22)
} 
Bentuk informasi yang didapat dari gaya bahasa litotes pada SMS di atas adalah memberikan sudut terhadap lembaga pemerintahan yang selalu tidak mengedepankan kepentingan masyarakat umum, "Uang $50 \mathrm{rb} / \mathrm{i} 00 \mathrm{rb}$, tinggaikan iah pola2 pemikiran ada uang dipiiih tak ada uang tdk dipiiih" dalam SMS tersebut pengirim mencoba untuk merendahkan calon wakil pemilihan rakyat yang menggunakan uang untuk mendapatkan suara terbanyak dalam suatu pemilihan.

Yth. kalapas malabro tlonglah di brantas pungli d ruang kniungan tu. idak sgalo orang tu ado duit. agus 2010 dlu lah d hapuskan kni ado igi. alahgkah cangkok BBM (D23)

Selanjutnya "kalapas malabro tlonglah di brantas pungli d ruang knjungan tu." Suatu bentuk litotes yang sangat merendahkan pejabat pemerintah. Pada kalimat SMS "Lapor Cik" di atas sangat jelas bahasa yang digunakan untuk menegaskan satu kalimat sehingga menjadi satu kesatuan bahasa.

b. Ironi

Gaya bahasa yang menyatakan makna yang bertentangan dengan maksud berolok-olok. Sementara itu, menurut Badudu (1984), gaya bahasa ironi adalah salah satu gaya bahasa sindiran, pada SMS Lapor Cik sebagai berikut.

Rakyat. Makan Saja hati nurani mereka telah gelap, tapi kami rakyat merasa malu miliki wakil kami yg tdk malu dan tdk menakyat. (D24)

Bentuk penggunaan gaya bahasa ironi di atas "Makan Saja hati nurani mereka telah gelap, tapi kami rakyat merasa malU miliki wakil kami yg tdk malu dan tdk merakyat". Hal tersebut memberikan sindiran terhadap pejabat daerah yang tidak memikirkan nasib rakyat.

Kasus lamo baru di jalani hukumannya, korupsi lagi sudah vonis, korupsi berlapis $Z$.

masih ngoceh dak bersalah, bakalan mati dalam kerangkeng korupsi lagi kau

mati kau dalam bui. ( D25)

Selanjutnya "Kasus lamo baru di jalani hukumannya, korupsi lagi sudah vonis, korupsi berlapis Z". Hal tersebut memberikan sindiran terhadap petugas pemerintahan yang lalai dalam menyelesaikan kasus yang ada pada pemerintahan. SMS "Lapor Cik" di atas menunjukkan bentuk sindiran.

\section{c. Oksimron}

Oksimoron merupakan sejenis gaya bahasa yang mengandung penegasan atau pendirian suatu hubungan sintaksis, baik koordinasi maupun determinasi antara dua antonim, pada SMS Lapor Cik sebagai berikut.

Untuk pdam kota bengkulu ado dak mato dan telingo pipa bocor di jln Rinjani uung sdh lebih 2 bln tdk kunjung di perbaiki. (D26) 
Syaiful Abid

Karakteristik Bahasa Teks SMS Kolom "Lapor Cik" Harian Rakyat Bengkulu

SMS di atas memberikan sindiran atau teguran kepada kepada pihak terkait serta penegasan dan permintaan.

SDN .. pungut uang Rp 6Orb per siswa u pngecatan sekolah tanpa prstujuan wali munid. Kadiknas tolong periksa pungutan tsb. Km gedung masih baru dan dpt dana DAK, BOS. (D27)

Fungsi dari oksimoron di sini adalah untuk sebuah gaya bahasa yang bersifat penegasan seperti pada "SDN .. pungut uang Rp 6Onb per siswa u pngecatan sekolah tanpa prstujuan wali munid. Kadiknas tobong pniksa pungutan tsb. Km gedung masih baru dan dpt dana DAK, BOS". Pada SMS tersebut terdapat sebuah penegasan yang menunjukkan bahwa sekolah tidak boleh memungut biaya atau dana tambahan daripada dana BOS.

d. Paralepsis

Gaya bahasa yang merupakan suatu formasi yang dipergunakan sebagai sarana untuk menerangkan bahwa seseorang tidak mengatakan apa yang tersirat dalam kalimat itu sendiri, pada SMS Lapor Cik sebagai berikut.

KORUPSI Bagi para koruptor amoral dianggapnya tidak berdosa tetapi merupakan seni: -Mencuri. -Menipu. -Menyuap. -Berkelit. -Melarikan din. TEMBAK MATI SAJA.!!! (D28)

Dalam SMS Lapor Cik ini pengirim memberikan informasi mengenai bahwa tidak ada keterikatannya dalam kalimat tersebut "KORUPSI Bagi para koruptor amoral dianggapnya tidak berdosa tetapi merupakan seni”. la hanya memberikan gambaran terhadap pelaku korupsi itu sendiri.

Orang2 yang suka memfitnah. Menghasut.Bermulut kasar.Suka menzalimi orang yang lemah. Suka berbuat jahat.Nanti saat meninggal orang2 seperti itu matinya. Mayatnya akan gOsOng inggal.Semoga kita termasuk orang2 yang beriman.Amin (D29)

Pada SMS di atas "orang2 yang suka memfitnah". Gambaran SMS ini memberikan arti bahwa seseorang tidak mengatakan apa yang dikehendaki dalam kalimat itu sendiri.

\section{Najarudin demokrat sdh tertangkap. Selanjut nya mampukah poll- Si nangkap}

istri adang dorojatun Coba yg mi berani tidak nangkap nyo. (D30)

Gaya bahasa yang disampaikan pada SMS "Lapor Cik" di atas merupakan sebagai sarana untuk menerangkan bahwa seseorang tidak mengatakan apa yang dikehendaki dalam kalimat itu sendiri.

e. Hiperbola

Gaya bahasa ini melibatkan kata-kata, frase, atau kalimat, pada SMS Lapor Cik sebagai berikut.

Kata orang buah jatuh tdk jauh dr batangnya. Ada yg berkata kalau anaknya beruk tentu bapaknya juga beruk. Lain lagi guru kencing berdiri murid kencing berlari (D31). 


\section{Syaiful Abid}

Karakteristik Bahasa Teks SMS Kolom "Lapor Cik" Harian Rakyat Bengkulu

Gaya bahasa hiperbola di atas menunjukkan bahwa "Kata orang buah jatuh tdk jauh dr batangnya". Ada yg berkata kalau anaknya beruk tentu bapaknya juga beruk" hal tersebut berarti suatu tingkah laku dan perilaku tidak akan jauh berbeda dengan atasannya pada suatu departemen pemerintahan yang ada. Contoh data majas hiperbola juga ada pada data SMS berikut.

Lap cik,knpa saling menylahkan pgri dgn kpla skolah tntng uang non sertfkasi?manjangkan tali kolor Aja (D32)

"Lap cik, knpa saing menylahkan pgri dgn kpla skolah tntng uang non sertfkasi?manjangkan tali kolor Aja" hal tersebut menunjukkan gaya bahasa yang tidak bertanggung jawab akan suatu tugas yang diberikan atau di emban.

\section{f. Sarkasme}

Sarkasme merupakan gaya bahasa yang mengandung olok-olok atau sindiran pedas dan menyakitkan hati. Pada SMS "Lapor Cik" dijumpai gaya bahasa sarkasme, adapun gaya bahasa tersebut sebagai berikut

\section{WAHAI TIKUS KANTOR, ,,,JANGAN SUKA GIGITIN KABEL LISTRIK DONG,,,,}

ENTAR KENA SETRUM MAMPUS LO,,,!!!!! XXXXXXXX,,(D33)

Dari uraian SMS Lapor Cik di atas, diambil beberapa bagian dari SMS Lapor Cik yang ada, uraian tersebut menggunakan gaya bahasa berdasarkan pilihan kata, tujuan penggunaan gaya bahasa tersebut menggunakan kata-kata yang familiar dan mudah dipahami oleh pembaca lainnya. Pada SMS pertama kata “WAHAI TIKUS KANTOR,,,,,JANGAN SUKA GIGITIN KABEL LISTRIK DONG”. Hal tersebut menunjukkan bahwa pilihan kata tersebut menunjukkan kefamiliaran kosakata dalam penggunaan bahasa SMS.

Pak Dr Nuzuar, mutasi abatan di instansi manapuni seharusnya tdk dibenarkan

KOLUSI dan NEPOTISME. Jadi bukan hanya di Diknas. Tempatkan!ah sesuai keahliannya (D34)

Pada sms tersebut dapat jenis pilihan kata yang diberikan adalah bersifat kata-kata yang populer dan umumnya banyak digunakan orang yang bersifat resmi dan tdak resmi karena tidak diperhatikan dari bentuk morfologis.

"Pak sekda kph yth. Staf bpk inisial ...n....digrebek masy dan polisi sedang mesum d kebun teh kbawetan " (D35)

Pada SMS tersebut merupakan gaya bahasa sindiran yang sangat pedas ditujukan kepada Baupati Kepahiang. Bahasa seperti ini umumnya banyak digunakan dari bentuk morpologis.

g. Antiklimaks

Antiklimaks yaitu suatu acuan yang berisi gagasan yang diurutkan dari yang terpenting berturut-turut ke gagasan yang kurang penting, pada SMS Lapor Cik sebagai berikut. 
RAKYAT MENUNTUT KEADILAN Mohon kepada penegak hukum untuk melakukan PKI Peninjauan Kembali. Termasuk kasus2 korupsi besar dimasalalu yang dibekukan \& SP3. Bahkan terhadap Vonis Bebas Hukuman dindikasikan keterlibatan MARKUS. (D36)

Pada SMS Lapor Cik "RAKYAT MENUNTUT KEADILAN. Mohon kepada penegak hukum untuk melakukan PKI Peninjauan Kembali. Termasuk kasus2 korupsi besar di masa lalu yang dibekukan \& SP3. Bahkan terhadap Vonis Bebas Hukuman diindikasikan keterlibatan MARKUS". Hal tersebut memberikan suatu gagasan atau ide yang bersifat penegasan kepada yang berwajib.

\title{
Korupsi/koruptor merupakan kejahatan kemanusiaan lebih kejam dan TERORIS.! Sebab hukum telah mati dibunuh oleh oknum2 mereka (D37) \\ Pada sms "Korupsi/koruptor merupakan kejahatan kemanusiaan lebih kejam dan TERORIS" memberikan suatu gagasan yang sangat tegas.
}

\begin{abstract}
LAPORCIK Mengapa masih banyak para karyawan pemerintah yg suka memper lambat/menghambat pelayan pada rakyat. Inilah satu2 nya penghambat laju nya pembangunan di segala bidang di daerah ini. Kemalasan atau memper lambat2 kerja kerna mau uang sogok itu sama dengan tingkah laku ...(peliharaan) saya diberi makan malah ticlur tidak peduli ada yg dating (D38)
\end{abstract}

Data di atas merupakan data yang disampaikan oleh pengirim SMS Lapor Cik yang termasuk ke dalam antiklimaks. Dalam SMS tersebut pernyataan yang berisi gagasan-gagasan yang disusun dengan urutan dari yang penting hingga yang kurang penting.

5) Gaya Bahasa Pertautan

Gaya bahasa pertautan pada SMS Lapor Cik terdapat beberapa majas, sebagai berikut.

a. Antonomasia

Gaya bahasa yang merupakan penggunaan gelar resmi atau jabatan sebagai pengganti nama diri.

PAK BUPATI BLI PASCA TDK ADA TES CPNS MHN DATA ULANG JUMLAH PNS BU MASING2 SKPD DAN KEMBALIKAN MEREKA YG MEMILIKI DISIPLIN ILMU DG JOBS YG TETAP SEPERTI SEKDIS SOSIAL KEMBALI JD TENAGA MEDIS.SEKDIS BLH SBG PEJABAT PETERNAKAN DLL ( D39)

Dari SMS Lapor Cik di atas singkatan atau gelar yang diberikan adalah bersifat formal. Hal ini ditujukan kepada orang yang dianggap lebih terhormat di kalangan masyarakat pada umumnya, seperti pada singkatan "bapak Bupati" hal tersebut menunjukkan bahwa bupati merupakan orang yang tertinggi di wilayah bagian kabupaten, sontoh selanjutnya sebagai berikut.

RP KAPOLRES RL berikan sangsi kpd kariawn kios yg si denijn ,teng KI modip bkn pmbli yg d tangkp bi perlu ganti kariawan br, krna itlh sumberya. (D40)

kemudian untk "Bpk. Kapolda" adalah menunjukkan orang yang tertinggi di kalalngan kepolisian resort wilayah bagian dari terbesar daerah tersebut. 
b. Erotis

Sejenis gaya bahasa yang berupa pertanyaan yang dipergunakan dalam tulisan atau pidato yang bertujuan untuk mencapai efek yang lebih mendalam dan penekanan yang wajar, dan sama sekali tidak menuntut jawaban.

\title{
RAKYAT TAU DAN BISA MEMBERI DUKUNGAN SKRG ZAMAN TRANSPARAN PAK
} YTH TP ANEH YTH SKRG MALAH YG USUL RAPAT TERTUTUP (D41)

Pada gaya bahasa erotis pesan yang terdapat dalam SMS tersebut menyebutkan bahwa yang diberikan oleh masyarakat terhadap perkembangan zaman dalam suatu pemerintahan. Pada SMS "Lapor Cik" di atas tersebut "ANEH YTH SKRG MALAH YG ,USUL RAPAT TERTUTUP”. kemudian "agr bpk menginstuksikan selurub PNS Kota dipoton gail nya 2 bulan zakat protest". Kalimat ini memberikan pengertian bahwa penekanan terhadap permintaan yang diberikan dalam kalimat tersebut merupakan gaya bahasa erotis yang memiliki makna penekanan pada kata sehingga membuat kesetaraan pada kalimat yang diungkapkan.

\section{Pak WAlikota sy mengharapkan kpd bpk sblm jbtn bpk berakhir thn depan agr bpk menginstuksikan selurub PNS Kota dipoton gail nya 2 bulan zakat protest (D42)}

\begin{abstract}
Pada sms tersebut diatas memiliki makna penekanan pada kata sehingga membuat kesetaraan pada kalimat yang diungkapkan oleh pengirim sms lapor cik.

kpd pihak manajemen bus sriwijayatlg $\mathrm{d}$ tegur iu vg briualan lontong di dpn area sriwijaya,klo bjualan tig mbok pake penutup hor mati. la kmi yg sdg brpuasa (D43)
\end{abstract}

Data di atas (D43) memberikan arti bahasa yang berupa pertanyaan yang tidak menuntut jawaban sama sekali.

c. Pararelisme

Pararelisme adalah semacam gaya bahasa yang berusaha mencapai tingkat kesejajaran, pada SMS Lapor CIK terdapat dalam kalimat sebagai berikut.

Antara Indonesia tenjalin hubungan yang sangat balk dengan Singapura, buktinya kalau korupsi di Indonesia lan di terima di Singapura hebatkan. (D44)

SMS Lapor cik tersebut di atas menggunakan gaya bahasa metafora dengan membandingkan dua peristiwa yang terjadi "Antara Indonesia terjalin hubungan yang sangat baik dengan Singapura". Dalam SMS ini pengirim berita menyampaikan keluh kesah yang dialami oleh rakyat Indonesia dengan adanya kasus korupsi international antara bangsa Indonesia dengan Singapura.

Menurut KHZAINUDDIN.MZ doa yg pasti diterima dan di kabulkan oleh ALLAH.SWT.

Adalah doa para Wali, tapi bukan walikota (D45).

Kemudian SMS ke-2 "doa para Wali, tapi bukan walikota". SMS ini membandingkan doa para wali islami terdahulu akan dikabulkan bukan berarti doa 


\section{Syaiful Abid}

Karakteristik Bahasa Teks SMS Kolom "Lapor Cik" Harian Rakyat Bengkulu

walikota sebagai pemimpin pemerintah pada saat ini. Pada SMS Lapor Cik tersebut merupakan suatu perbandingan yang bersifat setara antara anak kalimat dan induk kalimat yang diterangkan.

\section{Simpulan dan Saran}

Dari hasil penelitian yang dilakukan maka dapat disimpulkan bahwa penggunaan bahasa SMS "Lapor Cik" terdapat beberapa penggunaan bahasa, yaitu bahasa formal dengan persentase $0,03 \%$, penggunaan bahasa campuran (language mixing) dengan persentase $0,02 \%$, penggunaan bahasa asing yang disertakan bahasa Indonesia, atau sering disebut dengan language mixing (campur bahasa) dengan persentase $0,02 \%$, penggunaan bahasa gaul (slang) dengan persentase $0,14 \%$, dan penyingkatan kata dengan persentase $0,34 \%$, artinya dari keseluruhan penggunaan bahasa SMS "Lapor Cik" didominasi oleh penyingkatan kata.

Pada style (gaya) yang dapat dijumpai dalam SMS "Lapor Cik" pada Harian Rakyat Bengkulu yakni: (1) pertentangan, (2) perbandingan, (3) dan pertautan. Berdasarkan hasil pembahasan yang ada dapat kita ketahui bahwa penggunaan karakteristik bahasa yang dilihat dari penggunaan bahasa formal dan nonformal, slang atau yang sering juga disebut sebagi bahasa gaul serta kajian bahasa lainnya dengan menggunakan bahasa lokal.

Dari hasil penelitian ini baru sebatas meneliti karakteristik bahasa SMS secara deskriptif kualitatif sehingga dapat dijadikan dasar bagi peneliti lanjutan untuk mengkaji lebih dalam tentang karakteristik bahasa SMS pada surat kabar khususnya pada surat kabar Harian Rakyat Bengkulu dari sudut pandang lain. Peneliti lanjutan bisa mengkaji unsur bahasa yang lain seperti menggunakan metode semantik, analisis isi, atau bisa melihat dari sisi kesantunan berbahasanya.

\section{Daftar Pustaka}

Amelia, M. (2015). Gaya Bahasa Mahasiswa dalam Meminta Izin melalui SMS dan Respon Dosen. Lingua Didaktika: Jurnal Bahasa dan Pembelajaran Bahasa, 9(1), 37. doi:10.24036/ld.v9i1.6259

Ariyanti, T. D. \& Fentaria, I. (2017). Penggunaan Konjungsi dalam Wacana Kriminal Kolom Borgol di Surat Kabar Rakyat Bengkulu Edisi November - Desember 2016. Parafrase, 17(1), 29-40, https://doi.org/10.30996/parafrase.v17i1.1358

Badudu. J. S. (1984). Sari Kasusastraan Indonesia 2. Bandung: Pustaka Prima.

Farouq, M. A. Y. E. (2019). Analisis Peristiwa Alih Kode dan Campur Kode pada Novel Negeri 5 Menara Karya Ahmad Fuadi. Hasta Wiyata, 2(2), 14-25. doi:10.21776/ub.hastawiyata.2019.002.02.02

Keraf, G. (2004). Diksi dan Gaya Bahasa. Jakarta: Gramedia Pustaka Utama.

Moleong, L. J. (2013). Metode Penelitian Kualitatif. Edisi Revisi. Bandung: PT. Remaja Rosdakarya. 


\section{Syaiful Abid}

Karakteristik Bahasa Teks SMS Kolom "Lapor Cik" Harian Rakyat Bengkulu

Morelent, Y. (2013). Bahasa SMS dari Segi Grafologis, Sintaksis, dan Psikolinguistik serta Implikasinya terhadap Pembelajaran Bahasa Indonesia. Al-Ta Lim Journal, 20(3), 472-479. doi:10.15548/jt.v20i3.45

Samijayani, O. N., Rahsanjani, \& Iftikar, F. (2015). Perancangan Sistem Penulisan Teks pada Running Text Menggunakan SMS. Jurnal AL-Azhar Indonesia Seri Sains dan Teknologi, 2(3), 164. doi:10.36722/sst.v2i3.137

Sirulhaq, A., \& Chaer, H. (2019). Dekonstruksi Bahasa Indonesia pada Bahasa SMS. MABASAN, 5(1), 1-11. doi:10.26499/mab.v5i1.193

Sriningsih, E. (2017). Fitur Linguistik dan Non-Linguistik Penggunaan Bahasa SMS pada Siswa Smpn 4 Mataram dan Implikasinya terhadap Pembelajaran Bahasa Indonesia di Sekolah. RETORIKA: Jurnal IImu Bahasa, 1(2), 298308. doi:10.22225/jr.1.2.35.298-308

Susanti, D. (2013). Gaya Hidup Pengguna Telepon Seluler Blackberry. Manajemen Bisnis, 1(2). doi:10.22219/jmb.v1i2.1329

Syamsi, K. (2015). Perang Tarif dalam Industri Layanan Jasa Telepon Seluler: Analisis Wacana Iklan Operator Telepon Seluler di Media Massa. Diksi, 16(1). doi:10.21831/diksi.v16i1.6570

Yule, G. (1996). Pragmatik. Yogyakarta: Pustaka Pelajar. 